\title{
PENGARUH NON PERFORMING LOAN (NPL) DAN LOAN TO DEPOSIT RATIO (LDR) TERHADAP RETURN ON ASSET (ROA) PADA PERUSAHAAN PERBANKAN YANG TERDAFTAR DI BURSA EFEK INDONESIA
}

\author{
Randi Siregar ${ }^{1}$, Sabeth Sembiring ${ }^{2}$ \\ ${ }^{1,2}$ Universitas Katolik Santo Thomas Medan Jl. Setia Budi No. 479F, 20132, Indonesia \\ e-mail: sabethsembiring@gmail.com
}

\begin{abstract}
The purpose of this research was conducted to know the influence of: (1) Simultaneous Non Performing Loan and Loan to Deposit Ratio against Return On Asset, (2) Partial Non-Performing Loan against Return On Asset and (3) partial Loan to Deposit against Return On Asset Corporate Banking the Go Public period 2010 - 2012.The research uses quantitative research plans. The research subject is a banking company that go public from 2014 - 2016 and the objects are Non Performing Loan, Loan to Deposit Ratio and Return On Asset.Data collected using documentation methods and analyzed with multiple linear regression analyses. The results showed that (1) Non Performing Loan and Loan to Deposit Ratio simultaneously had significant effect on Return On Asset.(2) Non Performing Loan partially negative effect on Return On Asset, (3) Loan to Deposit Ratio positively affects the Return On Asset of the banking company listed on the Indonesia Stock Exchange.The value of the coefficient of determination (adjusted R2) of 0.323 or $32.3 \%$, this translates to $32.3 \%$ of ROA variations that can be explained by variations of independent variables of the NPL and LDR.The remaining $67.7 \%$ is explained by other reasons outside of the regression model.Based on the results of multiple linear regression analyses indicating that the NPL has a significant negative impact on ROA, LDR has a significant and positive effect on Roa, NPL and $L D R$.
\end{abstract}

Key Word: Non PerformingLoan Dan Loan To Deposit Ratio Return On Asset

\section{PENDAHULUAN}

Sekarang ini masalah perekonomian berkembang sangat pesat. Seiring dengan bertambahnya kebutuhan dan keinginan masyarakat atas pemenuhan usaha untuk mencapai kemakmuran. Dimana untuk mengembangkan bisnis atau menciptakan lapangan pekerjaan dibutuhkan modal yang besar, yang mungkin belum dimiliki oleh seseorang yang membutuhkan dana tersebut. Sedangkan prospek usaha yang sukses sudah didepan mata dan hanya terhalang dana yang belum mencukupi untuk dijadikan modal usaha. Dengan demikian industri perbankan hadir dengan menawarkan kemudahan untuk mendapatkan pinjaman uang yang dibutuhkan oleh masyarakat. Dengan ketentuan dan syarat tertentu maka bank sudah dapat membantu mengatasi masalah keuangan yang dialami oleh masyarakat.

ROA (Return On Asset) sekaligus sebagai variabel dependen digunakan penulis sebagai tolak ukur untuk mengukur kemampuan suatu perusahaan dalam menghasilkan laba karena $R O A$ dapat menunjukkan berapa laba yang diperoleh atas setiap rupiah yang tertanam dalam aktiva perusahaan yang bersangkutan. Namun selayaknya industri lain yang ada dan beroperasi, industri perbankan pun tak lepas dari tujuan utamanya yaitu menghasilkan laba. Dalam hal ini ROA dapat menunjukkan kinerja perusahaan perbankan. Disisi lain, bank dapat menghasilkan laba dari bunga atas pinjaman yang diberikan oleh bank. Namun dengan fungsi bank yang untuk membantu masalah keuangan nasabahnya maka bank harus memikirkan bagaimana cara menghasilkan laba dengan tanpa menyulitkan nasabah. Maka dari itu bank harus memikirkan berapa jumlah bunga yang tepat sehingga dapat memberikan keuntungan sebesar mungkin bagi pihak bank maupun masyarakat yang akan menjadi nasabah.

NPL (Non Performing Loan) adalah rasio yang digunakan penulis untuk mengukur sejauh mana kredit yang bermasalah dapat dipenuhi dengan aktiva produktif yang dumiliki oleh suatu bank. Dengan demikian bank harus mempertimbangkan solusi untuk meminimalisir kemungkinan risiko yang tidak diinginkan tersebut terjadi. NPL merupakan suatu rasio yang timbul karena nasabah tidak mampu membayar pinjaman beserta bunganya. Akan tetapi sebelum, memberikan pinjaman dengan jumlah 


\section{Volume 20 Nomor 2, September 2020}

besar kepada nasabah, bank juga harus mempertimbangkan risiko-risiko yang sekiranya berkaitan dengan pemberian pinjaman tersebut. Salah satunya risiko yang mungkin akan timbul adalah risiko kredit atau kredit macet.Solusi yang mungkin diberikan oleh bank dapat disesuaikan dengan besar kecilnya kemungkinan risiko.

LDR (Loan to Deposit Ratio) digunakan penulis dimana rasio ini dapat digunakan untuk mengetahui kemampuan bank dalam membayar kewajibannya. Selain dari bunga pinjaman, bank juga dapat mengasilkan keuntungan dengan memutar uang yang terkumpul banyak dari para nasabah tersebut dalam bentuk investasi, bisa dalam bentuk saham maupun dalam bentuk lain. LDR adalah kemampuan bank untuk memenuhi kewajibannya baik hutang jangka panjang maupun hutang jangka pendek. Selain itu bank juga memiliki kewajiban lain yaitu memberikan kelancaran pelayanan kepada nasabah yang ingin menyimpan maupun mengambil uangnya. Dengan demikian LDR bank juga harus diperhatikan agar bank tersebut dapat dikatakan baik dan mendapat kepercayaan penuh para nasabah.

Selama ini telah banyak terjadi masalah besar didunia perekonomian yang pada akhirnya memberi pengaruh besar pada eksistensi perbankan didunia. Namun masih banyak kalangan bankir meyakini bahwa tidak ada bank yang jatuh dan dilikuidasi karena rasio kredit bermasalah (Non Permorming Loan) yang tinggi. Sementara kebanyakan bankir meyakini bahwa likuiditas bank yang buruk atau tidak sehat bisa membunuh operasi bank sehingga operasi bank tersebut ditutup. Dimana pada krisis moneter pada 1997/1998 lalu menjadi contoh valid kegagalan pengelolaan bank karena likuiditasnya yang jatuh lantaran pengambilan tindakan yang sembrono dalam mengelola bank. Jadi, masuk akal apabila menjaga likuiditas menjadi pilihan prioritas seraya menyehatkan kualitas aset, terutama kredit.

Hasilnya pun terbukti, dimana berkat penerapan upaya tersebut kinerja bank-bank nasional tetap bertahan hingga sekarang. Mayoritas bank-bank kelas kakap yang resmi merilis laporan keuangan tahun 2013 memberi kabar baik lantaran pencapainnya sukses besar. Laba bersih mereka naik diatas $15 \%$ bidanding periode tahun 2012.

Selama ini banyak penelitian tentang profitabilitas, karena profitabilitas merupakan hal yang penting dan diperhatikan banyak pihak, baik investor maupun kreditor. Penelitian ini merupakan penelitian replikasi dari penelitian Adriyanti (2011) dan paramita dkk (2014).

Adriyanti (2011) membahas dengan judul "Pengaruh Non Performing Loan (NPL) dan Loan to Deposit Ratio (LDR) Terhadap Return On Assets (ROA)pada Bank BUMN di Indonesia pada tahun 2006-2009" variabel yang diteliti adalah risiko kredit dan likuiditas sebagai variabel independen dan profitabilitas adalah variabel dependen, dengan hasil penelitian bahwa NPL berpengaruh signifikan negatif terhadap ROA dan LDR berpengaruh signifikan positif terhadap ROA selain itu NPL dan LDR secara bersama-sama memiliki pengaruh terhadap ROA.

Paramitha dkk (2014) membahas mengenai "Pengaruh Risiko Kredit dan Likuiditas Terhadap Profitabilitas pada Perusahaan Perbankan yang Go Public periode 2010-2012". Variabel yang diteliti adalah risiko kredit (NPL) dan likuiditas (CR) sebagai variabel independen, profitabilitas (ROA) sebagai variabel dependen. Dengan hasil penelitian Risiko Kredit dan Likuiditas secara simultan berpengaruh signifikan terhadap profitabilitas, Risiko Kredit berpengaruh negatif secara parsialterhadap profitabilitas pada perusahaan yang Go Public.Sedangkan penelitian yang penulis lakukan yaitu pada tahun (2018) yang juga membahas mengenai Risiko Kredit (NPL), Likuiditas (LDR) dan Profitabilitas (ROA). Sehingga berdasarkan penelitian mereka tersebut, maka peneliti dapat membandingkan dan menemukan perbedaan pada alat ukur yang digunakan oleh paramita yaitu $(C R)$, tahun penelitian dan pendapat.

Berdasarkan penjelasandiatas, maka peneliti merumuskan masalah sebagai berikut: ApakahNPL dan LDR berpengaruh secara parsial dan simultan terhadap ROA pada perusahaan perbankan yang terdaftar di Bursa Efek Indonesia?

\section{TINJAUAN PUSTAKA}

\section{Non Performing Loan (NPL)}

NPL dan bank adalah dua hal yang tidak bisa dipisahkan satu sama lainnya. Tingkat NPL timbul karena debitur tidak dapat mengembalikan dana yang dipinjam dan bunga yang harus dibayarkan 


\section{Volume 20 Nomor 2, September 2020}

kepada bank. Namun NPL ini harus diantisipasi oleh bank melalui suatu proses penilaian, analisis kredit yang benar dan tepat yang disesuaikan dengan prudential banking legal lending limit. Pada dasarnya kehadiran bank sampai sekarang ditengah masyarakat juga berkat keberanian manajemen bank tersebut dalam mengambil risiko. Namun jika risiko tersebut tidak dikelola dengan baik dan benar, maka bank dapat mengalami kegagalan bahkan pada akhirnya dapat mengalami kebangkrutan.

Non Performing Loan (NPL), dipilih penulis sebagai rasio dari kredit macet dikarenakan NPL dapat digunakan untuk mengukur sejauh mana kredit yang bermasalah yang ada dapat dipenuhi dengan aktiva produktif yang dimilki oleh suatu bank. Secara sistematis dapat dirumuskan sebagai berikut:

$$
N P L=\frac{\text { Pembiayaan Non Lancar }}{\text { Total Pembiayaan }} \times 100 \%
$$

Bringham (2001:57) Non Performing Loan (NPL) adalah perbandingan antara kredit bermasalah yang dimiliki bank dengan total kredit yang diberikan. NPL berpengaruh negatif terhadap kinerja perbankan. Semakin tinggi NPL maka semakin menurun kinerja atau ROA perbankan. Hal ini sejalan dengan adanya kredit bermasalah yang semakin besar dibandingkan dengan aktiva produktifnya, hal ini dapat mengakibatkan berkurangnya kesempatan untuk memperoleh pendapatan (Income) dari kredit yang diberikan, sehingga mengurangilaba dan berpengaruh buruk pada rentabilitas (ROA) bank. Agar kinerja bank tersebut dikatakan baik, maka setiap bank harus menjaga NPL-nya agar tetap dibawah 5\%. Dimana hal ini seperti yang sudah ditentukan oleh Bank Indonesia.

\section{Loan to Deposit Ratio (LDR)}

Latumaerissa (1999:23) menyatakan LDR adalah suatu pengukuran tradisional menunjukkan deposito berjangka, giro, tabungan dan lain-lain yang digunakan mengukur tingkat likuiditas. Rasio yang tinggi menunjukkan bahwa suatu meminjamkan seluruh dananya (loan-up) atau relatif tidak likuid (illiquit). Sebaliknya yang rendah menunjukkan bank yang likuid dengan kelebihan kapasitas dana yang siap dipinjamkan. LDR disebut juga rasio kredit terhadap total dana pihak ketiga yang digunakan untuk mengukur dana pihak ketiga yang disalurkan dalam bentuk kredit. Penyaluran kredit merupakan kegiatan utama bank, oleh karena itu sumber pendapatan utama bank berasal dari kegiatan ini. Semakin besarnya penyaluran dana dalam bentuk kredit dibandingkan dengan deposit atau simpanan masyarakat pada suatu bank membawa konsekuensi semakin besarnya risiko yang harus ditanggung oleh bank yang bersangkutan.

Menurut Mulyono (1995:101), Rasio LDR merupakan rasio perbandingan antara jumlah dana yang disalurkan ke masyarakat (kredit) dengam jumlăh dana masyarakat dan modal sendiri yang digunakan. Rasio ini menggambarkan kemampuan bank membayar kembali penarikan yang dilakukan nasabah deposan dengan mengandalkan kredit yang diberikan sebagai sumber likuiditasnya. Semakin tinggi rasio ini semakin rendah pula kemampuan likuiditas bank. Sebagian praktisi perbankan menyepakati bahwa batas aman dari LDR suatu bank sekitar 85\%. Namun batas toleransi berkisar antara 85\%-100\% atau menurut Kasmir (2003:272), batas aman untuk LDR menurut peraturan pemerintah adalah maksimun $110 \%$. Tujuan penting dari perhitungan LDR adalah untuk mengetahui serta menilai sampai berapa jauh bank memiliki kondisi sehat dalam menjalankan operasi atau kegitan usahanya. Dengan kata lain LDR digunakan sebagai suatu indikator untuk mengetahui tingkat kerawanan suatu bank.

Jumingan (2005:244) Pada dasarnya Loan to Deposit Ratio digunakan untuk mengetahui kemampuan bank dalam membayar kembali kewajibannya kepada deposan dengan menarik kembali kredit-kredit yang telah diberikan kepada para debiturnya. Dengan demikian rasio ini dapat dihitung dengan rumus sebagai berikut:

\section{Return On Asset (ROA)}

$$
L D R=\frac{\text { TotalLoans }}{\text { TotalDeposit }} \times 100 \%
$$

ROA adalah rasio untuk menunjukkan perbandingan antara laba dengan aktiva atau modal yang kemudian menghasilkan laba tersebut. Dengan kata lain ROA adalah rasio mengukur kemampuan suatu perusahaan untuk mencapai laba.Menurut Sugiyarso dkk (2005:118) "ROA adalah kemampuan perusahaan memperoleh laba dalam hubungan dengan penjualan total aktiva maupun modal sendiri." 


\section{Volume 20 Nomor 2, September 2020}

Sofyan Syafri Harahap (2011:305) Rasio ini menggambarkan perputaran aktiva diukur dari volume penjualandan dapat menunjukkan kemampuan modal yang diinvestasikan dalam keseluruhan aktiva perusahaan untuk menghasilkan keuntungan bersih. Semakin besar rasio ini semakin baik. Hal ini berarti bahwa aktiva dapat lebih cepat berputar dan meraih laba. Dengan kata lain, rasio ini dapat menunjukkan berapa laba yang diperoleh atas setiap rupiah yang tertanam dalam aktiva perusahaan yang bersangkutan. Rumus yang digunakan adalah sebagai berikut:

$$
R O A=\frac{\text { Net Income }}{\text { Total Asset }} \times 100 \%
$$

\section{METODE PENELITIAN}

\section{Populasi dan Sampel}

Dalam penelitian, populasi merujuk pada sekumpulan individu dengan karakteristik kas yang menjadi perhatian dalam satu penelitian atau pengamatan . "Populasi yang digunakan dalam penelitian ini adalah perusahaan-perusahaan dari industri perbankan yang terdaftar di Bursa Efek Indonesia (BEI) sampai tahun 2016 yang berjumlah 41 perusahaan perbankan.

Metode penentuan sampel yang digunakan adalah penentuan sampel secara purposive sampling, yang artinya pengambilan sampel didasarkan pada pertimbangan atau tujuan tertentu.

Perusahaan-perusahaan yang menjadikan sampel menggunakan purposivesamplingdalam penelitian ini adalah perusahaan perbankan yang terdaftar di Bursa Efek Indonesia (BEI) pada tahun 2014, 2015,2016, yang mana mempunyai kriteria sebagai berikut:a).Jumlah perusahaan perbankan yang terdaftar di bursa efek indonesia, b)Perusahaan yang dilisting dari Bursa Efek Indonesia selama periode 2014-2016., c) Perusahaan yang menyajikan laporan keuangan secara berturut-turut yaitu dari tahun 2014-2016, d) Perusahaan sampel yang memiliki semua data yang diperlukan seraca lengkap dari variabel yang diteliti, e) Laporan keuangan yang menggunakan mata uang rupiah indonesia, f).Laporan keuangan yang tidak diaudit oleh KAP.

\section{Operasionalisasi Variabel}

Penelitian ini menggunakan variabel independen (bebas) dan variabel dependen (terikat). Variabel-variabel tersebut yang digunakan dalam penelitian ini adalah sebagai berikut:

Tabel 1.Definisi Operasional dan Pengukuran Variabel

\begin{tabular}{|c|c|c|c|}
\hline Variabel & Devenisi Operasional & Indikator & Skala \\
\hline ROA (Y) & $\begin{array}{l}\text { Perbandingan antara laba dengan } \\
\text { aktiva atau modal yang kemudian } \\
\text { menghasilkan laba tersebut. }\end{array}$ & $\begin{array}{l}R O A \\
=\frac{\text { Net Income }}{\text { Total Asset }} \times 100 \%\end{array}$ & $\begin{array}{l}\text { Return On } \\
\text { Asset (ROA) }\end{array}$ \\
\hline NPL (X1) & $\begin{array}{l}\text { Suatu risiko akibat kegagalan atau } \\
\text { ketidakmampuan nasabah } \\
\text { mengembalikan jumlah pinjaman } \\
\text { beserta bunganya yang diperoleh dari } \\
\text { bank sesuai dengan jangka waktu yang } \\
\text { telah ditentukan sebelumnya. }\end{array}$ & $\begin{array}{l}\quad N P L \\
=(\text { Pembiayaan Non lanca } \\
/(\text { Total Pembiayaan }) \times 100\end{array}$ & $\begin{array}{l}\text { Non } \\
\text { Performing } \\
\text { Loan (NPL) }\end{array}$ \\
\hline LDR (X2) & $\begin{array}{l}\text { Kemampuan untuk memenuhi } \\
\text { kewajibannya dan atau kebutuhan } \\
\text { dana segera mungkin dan dengan } \\
\text { biaya yang sesuai. }\end{array}$ & $\begin{array}{l}\text { LDR } \\
=\frac{\text { Total Loans }}{\text { Total Deposit }} \times 100 \%\end{array}$ & $\begin{array}{l}\text { Loan to } \\
\text { Deposit Ratio } \\
\text { (LDR) }\end{array}$ \\
\hline
\end{tabular}

\section{Teknik Pengumpulan Data}

Teknik pengumpulan data sekunder pada penelitian ini dilakukan dengan melalui dua tahap. Tahap pertama yaitu dengan melakukan studi pustaka, yakni me-review jurnal akuntansi, serta buku- 


\section{Volume 20 Nomor 2, September 2020}

buku yang memilki kaitan dan berhubungan dengan penelitian ini. Tahap ke-dua yaitu dilakukan dengan cara men-download laporan keuangan perusahaan perbankan melalui situs www.idx.co.id.

Teknik Analisis Data

Analisis data dalam penelitian ini menggunakan metode analisis statistik yang menggunakan Regresi Linear Berganda dan menggunakan sofware atau SPSS 22. Adapun tahapan yang dilakukan dalam menganalisis penelitian ini adalah sebagai berikut:

\section{Pengujian hipotesis}

Uji t

Pengujian ini dilakukan untuk mengetahui apakah terdapat pengaruh signifikan dari NPL dan LDR secara parsial terhadap ROA pada perusahaan perbankan yang terdaftar di Bursa Efek Indonesia untuk peroide 2014-2016.

\section{Uji F}

Uji F dilakukan untuk mengetahui apakah terdapat pengaruh signifikan dari NPL dan LDR secara simultan terhadap ROA pada perusahaan perbankan yang terdaftar di Bursa Efek Indonesia.

\section{Pengujian Asumsi Klasik Uji Normalitas.}

Uji ini berguna untuk tahap awal dalam metode pemilihan analisis data. Menurut Erlina (2011:100), "Data normal, gunakan statistik parametrik dan jika data tidak normal, gunakan statistik non parametrik atau lakukan treatmentagar data normal."

\section{Uji Multikolinearitas}

Uji multikolinearitas bertujuan untuk menguji variabel independen yang memiliki kemiripan dengan variabel independen lainnya dalam suatu model. Menurut erlina(2011:102), "Model regresi yang baik seharusnya tidak terjadi korelasi diantara variabel independen, maka variabel independen tidak orthogonal. Yang dikatakan variabel independen yang bersifat orthogonal adalah variabel independen yang memiliki nilai korelasi diantara sesamanya sama dengan nol.

\section{Uji Heteroskedastisitas}

Menurut Ghozali (2011:139), "Uju Heteroskedastisitas bertujuan untuk menguji apakah dalam model regresi terjadi ketidaksamaan variance dari residual satu kepengamatan yang lain." Jika variance dari residual satu pengamatan kepengamatan yang lain tetap maka disebut homoskedastisitas dan jika berbeda disebut heteroskedastisitas. Model regresi yang baik adalah yang homoskedastisitas atau tidak terjadi heteroskedastisitas.

\section{Uji Autokorelasi}

Menurut Erlina (2011:105), “ Uji Autokorelasi bertujuan menguji apakah dalam suatu model regresi linear ada korelasi antara kesalahan pengganggu pada periode " $t$ " dengan kesalahan pada periode " $\mathrm{t}$ " - 1 atau sebelummnya." Uji yang dapat digunakan untuk mendeteksi masalah autokorelasi adalah dengan uji Durbin-Watson, karena uji ini yang umum digunakan.

\section{Uji Regresi Berganda}

Uji regresi berganda dilakukan untuk mengetahui sejauh mana variabel independen mempengaruhi variabel dependen dalam penelitian. Pada regresi berganda terdapat satu variabel dependen dan lebih dari satu variabel independen. Dalam penelitian ini yang menjadi variabel dependen adalah ROA, sedangkan variabel independen adalah NPL dan LDR.

Adapun model hubungan ROA dengan variabel-variabel tersebut dapat disusun dalam persamaan sebagai berikut:

$\mathrm{Y}=\alpha+b 1 \mathrm{NPL}+b 2 \mathrm{LDR}+e$

Dimana:

$\alpha=$ Konstanta 


\section{Volume 20 Nomor 2, September 2020}

$\mathrm{b} 1, \mathrm{~b} 2=$ Koefisien Regresi dari $\mathrm{X}_{1}, \mathrm{X}_{2}$

e $\quad=$ Error Term

\section{HASIL PENELITIAN DAN PEMBAHASAN}

\section{Hasil Penelitian}

Dari data mentah yang sudah tersedia dapat dilihat nilai minimum, maximum, mean dan standar deviasi dari masing-masing variabel penelitian pada tabel ini, sebagai berikut:

Tabel 1. Perhitungan nilai minimum, maximum, mean dan standar deviasi Descriptive Statistics

\begin{tabular}{|l|r|r|r|r|r|}
\hline & N & Minimum & Maximum & Mean & Std. Deviation \\
\hline NPL & 42 &, 0021 &, 5959 &, 034500 &, 0893182 \\
\hline LDR & 42 &, 1274 &, 2820 &, 191257 &, 0371595 \\
\hline ROA & 42 &, 0014 &, 0305 &, 015736 &, 0087239 \\
\hline Valid N (listwise) & 42 & & & & \\
\hline
\end{tabular}

Sumber: hasil penelitian, 2018 (data diolah menggunakan aplikasi SPSS 22)

Berdasarkan hasil perhitungan pada tabel 1 tersebut dapat dilihat bahwa dari 14 yang menjadi sampel, variabel dependen (ROA) mempunyai nilai rata-rata (mean) sebesar $1,57 \%$, besarnya ROA sesuai dengan aturan BI yaitu ROA yang baik harus diatas 1,50\%. Rata-rata NPL berdasarkan perhitungan tersebut adalah 3,45\% sedangkan NPL yang baik itu menurut BI harus dibawah 5\%. Sedangkan rata-rata LDR sebesar $19,12 \%$, besarnya LDR tersebut tidak sesuai dengan aturan BI yaitu LDR yang baik antara $80 \%-110 \%$.

\section{Uji Asumsi Klasik}

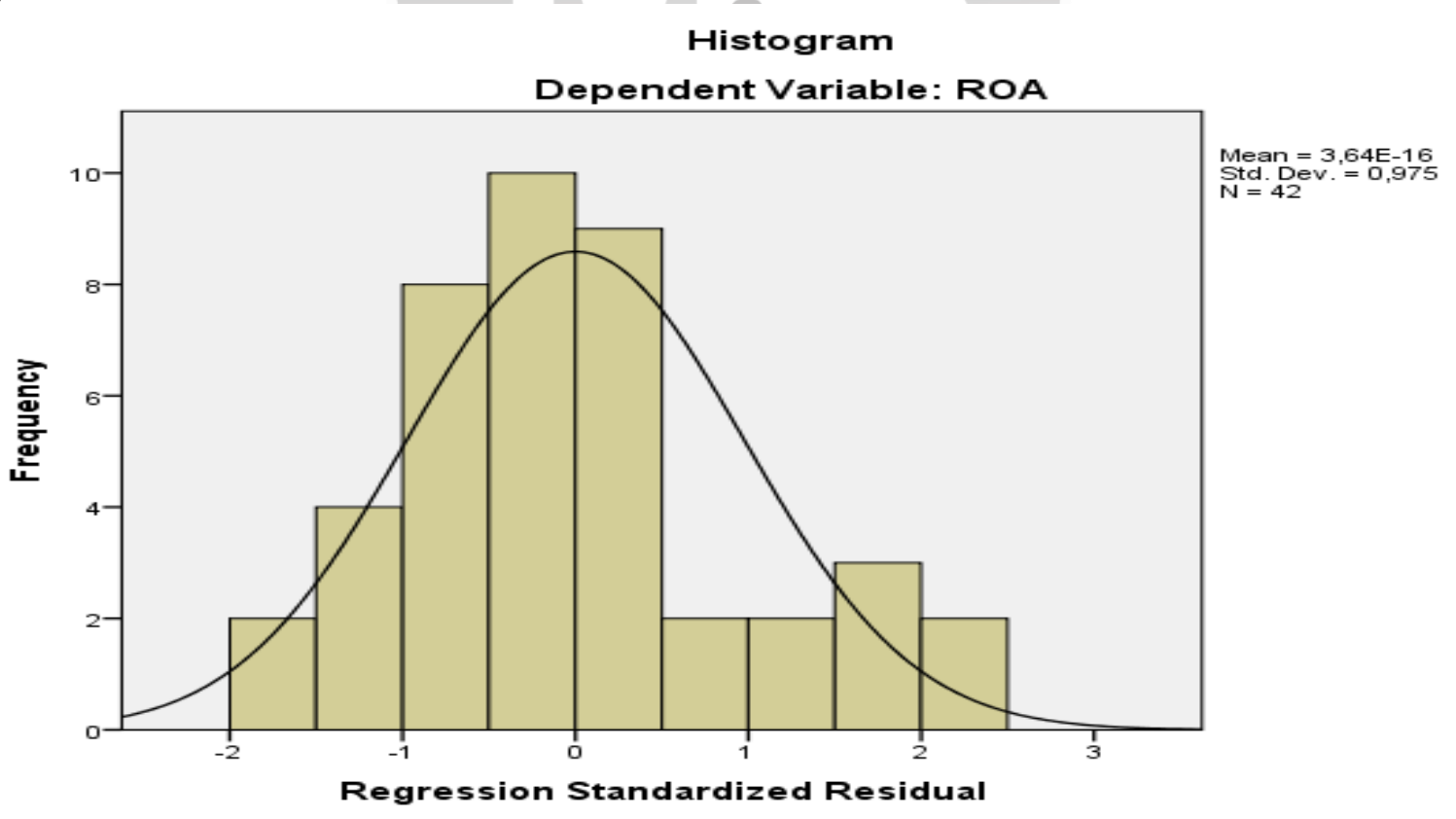

Gambar 1. Grafik Histogram

Sumber: hasil penelitian, 2018 (data diolah menggunakan aplikasi SPSS 22)

\section{Uji Normalitas.}

Metode yang handal adalah dengan melihat normal probability plot, dimana pada grafik normal plot terlihat titik-titik menyebar disekitar garis diagonal serta penyebarannya mengikuti arah garis diagonal, sebagaimana ditampilkan pada gambar 2. berikut: 


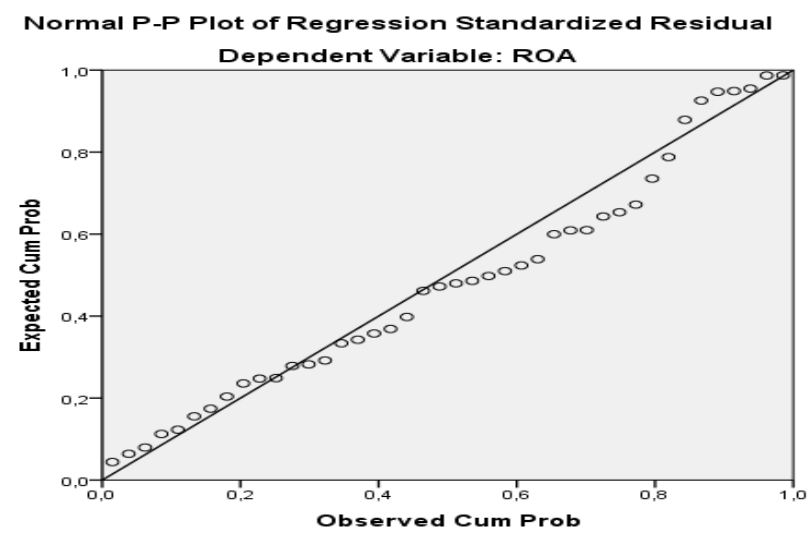

Gambar 2.Uji Normalitas

Sumber: hasil penelitian, 2018 (data diolah menggunakan aplikasi SPSS 22)

Jika dilihat berdasarkan grafik normal plot terlihat titik-titik menyebar tidak jauh dari garis diagonal. Hal ini menunjukkan bahwa grafik pola distribusi normal, maka model regresi memenuhi asumsi mormalitas.

\section{Uji Multikolinearitas}

Dalam mendeteksi ada tidaknya gejala multikolinearitas antar variabel independen pada model persamaan pertama digunakan variance inflation factor (VIF). Berdasarkan hasil yang ditunjukkan dalam output SPSS maka besarnya VIF dari masing-masing variabel independen dapat dilihat pada tabel 2. sebagai berikut:

Tabel 2. Hasil Perhitungan VIF Coefficients ${ }^{\mathrm{a}}$

\begin{tabular}{|l|l|r|r|}
\hline \multicolumn{2}{|c|}{ Model } & \multicolumn{2}{|c|}{ Collinearity Statistics } \\
\cline { 3 - 4 } & Tolerance & \multicolumn{1}{c|}{ VIF } \\
\hline \multirow{3}{*}{1} & (Constant) & & \\
\cline { 2 - 4 } & NPL &, 984 & 1,017 \\
\cline { 2 - 4 } & LDR &, 984 & 1,017 \\
\hline
\end{tabular}

Sumber: hasil penelitian, 2018 (data diolah menggunakan aplikasi SPSS 22)

Uji Heteroskedastisitas

Berikut ini adalah hasil uji heteroskedastisitas menggunakan uji glejser dapat ditunjukkan dalam tabel 3. berikut ini:

Tabel 3. Coefficients ${ }^{\mathrm{a}}$

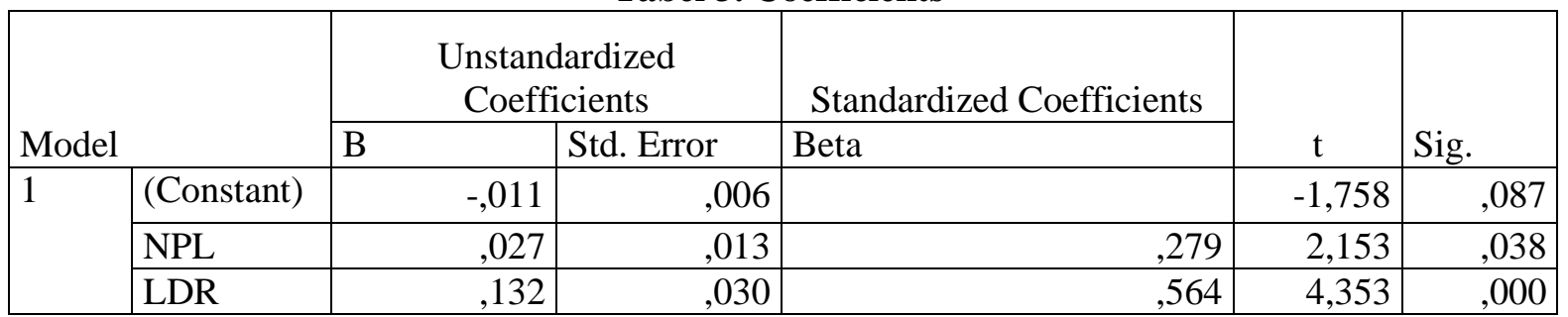

Sumber: hasil penelitian, 2018 (data diolah menggunakan aplikasi SPSS 22)

a. Dependent Variable: ROA

Berdasarkan tabel diatas terlihat bahwa nilai signifikansi variabel NPL adalah 0,038 < dari 0,05, demikian juga dengan variabel LDR sebesar $0,000<$ dari 0,05 . Maka dapat disimpulkan bahwa dalam penelitian ini terjadi heteroskedastisitas.

Uji Autokorelasi 


\section{Volume 20 Nomor 2, September 2020}

Penyimpanan autokorelasi dalam penelitian ini diuji dengan uji Durbin-Watson (DW-test). Hasil regresi dengan level of signifikan $0,05(\alpha=0,05)$ dengan variabel independen sejumlah 2 dan banyak data sejumlah $42(\mathrm{n}=52)$. Adapun hasil dari uji autokorelasi dapat dilihat pada tabel 4.8 berikut ini:

Tabel 4. Uji Autokorelasi Model Summary ${ }^{\mathrm{b}}$

\begin{tabular}{|l|r|r|r|r|r|}
\hline Model & R & R Square & Adjusted R Square & Std. Error of the Estimate & Durbin-Watson \\
\hline 1 &, $596^{\mathrm{a}}$ &, 356 &, 323 &, 0071794 & 1,594 \\
\hline
\end{tabular}

Sumber: hasil penelitian, 2018 (data diolah menggunakan aplikasi SPSS 22)

a. Predictors: (Constant), LDR, NPL

b. Dependent Variable: ROA

Berdasarkan tabel 4. menunjukkan hasil dari uji autokorelasi dengan menggunakan metode Durbin-Watson (DW) bahwa nilai Durbin-Watson (d) sebesar 1,594 lebih besar dari nilai batas atas (du) 1,5596 dan kurang dari nilai $4-1,6061(4-\mathrm{du})$ sebesar 2,68701 yang berarti tidak terdapat autokorelasi positif pada model regresi linear

\section{Analisis Regresi Berganda}

Analisis pengaruh rasio keuangan (Non Performing Loan (NPL) dan Loan to Deposit Ratio (LDR)) terhadap Return On Asset (ROA) pada perusahaan perbankan yang terdaftar di bursa efek indonesia (BEI) dapat dilihat dari hasil analisis regresi berganda. Pengujian koefisien regresi bertujuan untuk menguji signifikansi hubungan antara variabel independen $(\mathrm{X})$ dengan variabel dependen $(\mathrm{Y})$ baik secara bersama-sama (dengan uji F) maupun secara individual (dengan uji t) serta dengan uji koefisien determinasi. Dalam penelitian ini uji hipotesis yang digunakan meliputi: uji parsial (t-test), uji pengaruh simultan (F-test), uji koefisien determinasi $\left(\mathrm{R}^{2}\right)$.

\section{Uji Hipotesis}

\section{Uji parsial (t-test)}

Berdasarkan hasil output SPSS nampak bahwa pengaruh secara parsial dua variabel independen tersebut Non Performing Loan (NPL) dan Loan to Deposit Ratio (LDR) terhadap Return On Asset (ROA) seperti ditunjukkan pada tabel 3 di atas. Dari hasil analisis regresi linear berganda dengan program SPSS seperti terlihat pada tabel 5. persamaan regresi linear yang berbentuk adalah:

$\mathrm{ROA}=0,011+0,027 \mathrm{NPL}+0,132 \mathrm{NPL}+e$ berikut:

Dari hasil persamaan regresi linear berganda tersebut diatas maka dapat dianalisis sebagai

1. Non Performing Loan (NPL).

Dari hasil perhitungan uji secara parsial diperoleh nilai t hitung sebesar 2,153 dengan nilai signifikansi sebesar 0,038. Karena nilai signifikansi lebih kecil dari 5\% dan nilai t hitung sebesar 2,153 lebih besar dari t tabel sebesar 1,68288, sehingga dapat diindikasikan adanya pengaruh signifikan negatif antara variabel NPL terhadap variabel ROA. Adanya pengaruh signifikan negatif yang ditunjukkan oleh NPL tersebut mengindikasikan bahwa semakin tinggi kredit macet dalam pengelolaan kredit bank yang ditunjukkan dalam NPL maka akan menurunkan tingkat pendapatan bank yang tercermin melalui ROA.

2. Loan to Deposit Ratio LDR.

Dari hasil perhitungan uji secara parsial diperoleh nilai t hitung sebesar 4,353 dengan nilai signifikan 0,000. Nilai signifikan lebih kecil dari 5\% dan nilai t hitung 4,353 lebih besar dari t tabel 1,68288. Hasil penelitian ini mengindikasikan bahwa besarnya LDR perbankan berpengaruh signifikan positif terhadap ROA.

\section{Uji pengaruh simultan (uji F)}




\section{Volume 20 Nomor 2, September 2020}

Berdasarkan hasil output SPSS nampak bahwa pengaruh secara bersama-sama variabel independen tersebut (NPL dan LDR) terhadap variabel dependen (ROA) seperti ditunjukkan pada tabel 4.10 sebagai berikut:

Tabel 6. Hasil Perhitungan Uji Pengaruh Simultan ANOVA ${ }^{a}$

\begin{tabular}{|l|l|lr|r|r|r|r|}
\hline \multicolumn{2}{|l|}{ Model } & Sum of Squares & Df & Mean Square & F & Sig. \\
\hline \multirow{3}{*}{1} & Regression &, 001 & 2 &, 001 & 10,770 &, $000^{\mathrm{b}}$ \\
\cline { 2 - 9 } & Residual &, 002 & 39 &, 000 & & \\
\cline { 2 - 9 } & Total &, 003 & 41 & & & \\
\hline
\end{tabular}

Sumber: hasil penelitian, 2018 (data diolah menggunakan aplikasi SPSS 22)

a. Dependent Variable: ROA

b. Predictors: (Constant), LDR, NPL

Dari hasil perhitungan diperoleh nilai $\mathrm{F}$ hitung sebesar 10,770 yang lebih besar dari $\mathrm{F}$ tabel sebesar 3,22 dan nilai signifikansi sebesar 0,000. Karena nilai signifikansi lebih kecil dari 5\% maka model layak (goodness of fit). Yang artinya HOditolak dan Ha diterima sehingga terdapat pengaruh positif signifikan antara variabel NPL dan LDR bersama-sama berpengaruh positif dan signifikan terhadap kinerja perusahaan perbankan (ROA).

\section{Koefisien Determinasi $\left(\mathbf{R}^{2}\right)$}

Uji koefisien determinasi digunakan untuk menguji goodness of fitdari model regresi. Berdasarkan hasil output SPSS besarnya nilai adjusted $\mathrm{R}^{2}$ dapat dilihat pada tabel 7 sebagai berikut:

Tabel 7.Uji Koefisien Determinasi $\left(\mathbf{R}^{2}\right)$ Model Summary ${ }^{\mathbf{b}}$

\begin{tabular}{|l|r|r|r|rr|}
\hline Model & R & & R Square & Adjusted R Square & Std. Error of the Estimate \\
\hline 1 &, $596^{\mathrm{a}}$ &, 356 &, 323 &, 0071794 \\
\hline
\end{tabular}

Sumber: hasil penelitian, 2018 (data diolah menggunakan aplikasi SPSS 22)

a. Predictors: (Constant), LDR, NPL

b. Dependent Variable: ROA

Dilihat pada tabel diatas, nilai koefisien determinasi (adjusted $\overline{\mathrm{R}}^{2}$ ) sebesar 0,323 atau 32,3\%, hal ini berarti $32.3 \%$ variasi ROA yang bisa dijelaskan oleh variasi dari variabel independen yaitu NPL dan LDR. Sedangkan sisanya sebesar 67,7\% dijelaskan oleh sebab-sebab lain diluar model regresi. Standar error of estimate (SEE) sebesar 0,0071794, makin kecil nilai SEE akan membuat model regresi semakin tepat dalam memprediksi variabel dependen. TK S.

\section{PEMBAHASAN}

\section{Pengaruh NPL terhadap ROA}

Dari hasil pengujian secara parsial diketahui bahwa Non Performing Loan memiliki pengaruh signifikan negatif terhadap ROA. NPL menunjukkan t hitung sebesar 2,153 dengan nilai signifikansi sebesar 0,038, sedangkan $t$ tabel adalah 1,68288 sehingga $t$ hitung $>$ dari t tabel $(2,153>1,68288)$, maka Non Performing Loan (NPL)secara individual berpengaruh signifikan negatif terhadap Retun On Asset (ROA). Hasil pengujian menunjukkan bahwa hasil penelitian ini sesuai dengan hasil penelitian yang dilakukan oleh Adriyanti (2011) dan Paramitha dkk (2014) dimana hasil penelitiannyamenunjukkan bahwa Non Performing Loan (NPL) berpengaruh signifikan negatif terhadap Retun On Asset (ROA). JikaNon Performing Loan (NPL) naik makaRetun On Asset (ROA) akan turun, diakibatkan oleh jika kredit macet suatu bank relatif besar maka laba perusahaan itu akan turun karena sebagian dari modal bank tersebut sudah tertanam pada nasabah, pendapatan utama bank adalah dari bunga yang dipinjamkan. Koefisien regresi variabel Non Performing Loan (NPL) sebesar 0,027 menunjukkan bahwa setiap kenaikan Non Performing Loan (NPL) sebesar 1 akan menurunkan Retun On Asset (ROA) sebbesar 0,027 atau 2,7\% dengan asumsi variabel lain dianggap tetap. Hubungan Non Performing Loandan Retun On Assetmenurut hasil penelitian ini adalah negatif dimana Retun On Asset akan menurun jika nilai Non Performing Loan meningkat. 


\section{Volume 20 Nomor 2, September 2020}

\section{Pengaruh LDR terhadap ROA}

Dari hasil pengujian secara parsial diketahui bahwa Loan to Deposit Ratio (LDR) berpengaruh signifikan positif terhadap Retun On Asset (ROA). Loan to Deposit Ratiomenunjukkan t hitung sebesar 4,353 dengan nilai signifikansi 0,000, sedangkan $\mathrm{t}$ tabel sebesar 1,68288 sehingga $\mathrm{t}$ hitung $>\mathrm{t}$ tabel $(4,353>1,68288)$, maka Loan to Deposit Ratio (LDR) secara parsial berpengaruh signifikan positif terhadap Retun On Asset (ROA). Hasil pengujian menunjukkan bahwa hasil penelitian ini sesuai dengan hasil penelitian yang dilakukan oleh Adriyanti (2011) dimana hasil penelitiannya menunjukkan bahwa LDR berpengaruh signifikan positif terhadap ROA. Jika suatu bank dapat membayar hutang sebelum jatuh jampo pembayaran berarti bank tersebut mempunyai ROA yang baik karena untuk membayar hutang harus diambil dari laba yang diperoleh. Koefisien regresi variabel Loan to Deposit Ratio (LDR) 0,132 menunjukkan bahwa setiap kenaikan Loan to Deposit Ratio (LDR) sebesar 1, maka perubahan Return On Asset (ROA) yang dilihat dari Y akan meningkat sebesar 13.2\%.

\section{Pengaruh NPL dan LDR terhadap ROA}

Dari pengujian secara simultan bahwa Non Performing Loan(NPL)dan Loan to Deposit Ratio (LDR) berpengaruh signifikan terhadap Return On Asset (ROA) dengan F hitung sebesar 10,770 lebih besar dari $\mathrm{F}$ tabel yang menunjukkan angka sebesar 3,22 dengan nilai signifikansi 0,000, maka secara simultan Non Performing Loan (NPL)dan Loan to Deposit Ratio (LDR)berpengaruh signifikanterhadap Return On Asset (ROA). Hasil pengujian ini sesuai dengan penelitian yang dilakukan oleh Paramitha dkk (2014) yang menyatakan bahwa NPL dan LDR berpengaruh signifikan terhadap ROA.

\section{KESIMPULAN DAN SARAN}

\section{Kesimpulan}

1. Berdasarkan hasil pengujian menunjukkan secara parsial bahwa pada variabel Non Performing Loanberpengaruh signifikan negatif terhadap variabel Return On Asset yang ditunjukkan dengan besarnya tingkat signifikansi yaitu 0,038 lebih kecil dari 5\% dan nilai thitung sebesar 2,153 lebih besar dari t tabel sebesar 1,68288. Hubungan Non Performing Loan dan Return On Asset menurut hasil penelitian ini adalahnegatif dimana Return On Asset akan menurun jika nilai Non Performing Loan meningkat, begitu juga sebaliknya. Sehingga hipotesis 1 diterima.

2. Berdasarkan hasil pengujian menunjukkan secara parsial bahwa variabel Loan to Deposit Ratioberpengaruh signifikan positif terhadap variabel Return On Asset, hal tersebut ditunjukkan dengan tingkat signifikansi sebesar 0,000 lebih kecil dari 5\% dan nilai t hitung 4,353 lebih besar dari t tabel yaitu sebesar 1,68288. Hasil ini menunjukkan bahwa peningkatan maupun penurunan pada variabel Loan to Deposit Ratio memberikan pengaruh signifikan positif terhadap Return On Asset. Sehingga hipotesis 2 diterima.

3. Berdasarkan hasil pengujian, menunjukkan secara simultan bahwa variabel Non Performing Loandan Loan to Deposit Ratio berpengaruh terhadap variabel Return On Asset. Dimana nilai F hitung sebesar 10,770 yang lebih besar dari $\mathrm{F}$ tabel sebesar 3,22 dan nilai signifikansi 0,000. Karena nilai signifikansi lebih kecil dari 5\% maka hipotesis diterima. Hal ini menun jukkan peningkatan variabel Non Performing Loan dan Loan to Deposit Ratio secara simultan akan mengakibatkan peningkatan dan penurunan terhadap Return On Asset. Dari hasil ini dapat disimpulkan bahwa Non Performing Loandan Loan to Deposit Ratiosecara bersama-sama berpengaruh terhadap variabel Return On Assetperbankan tahun 2014-2016.

\section{Saran}

Setelah mengkaji hasil penelitian ini maka implikasi manajerial yang dapat penulis ajukan adalah sebagai berikut:

1. Bagi perusahaan perbankan, diharapkan agar lebih memperhatikan faktor fundamental perusahaan yang pada penelitian ini mempunyai pengaruh signifikan terhadap variabel profitabilitas.

2. Bagi peneliti selanjutnya diharapkan menambah variabel atau sampel penelitian, karena variabel dan sampel yang berbeda akan menimbulkan pengaruh yang berbeda pula sehingga hasil penelitian selanjutnya lebih akurat. 


\section{DAFTAR PUSTAKA}

Adriyanti, Rini. (2011) "Pengaruh non performing loan (NPL)dan loan to deposit ratio (LDR) terhadap return on assets (ROA)pada bank BUMN di Indonesia", Skripsi, Universitas Hasanuddin, Makassar.

Bringham, Eugene F. Dan Houston F. Joel, 2001. Manajemen Keuangan. Terjemahan Dodo Suharto dan Herman Wibowo. Financial Management . Edisi Kedelapan, Jilid 1. Jakarta:Erlangga.

Erlina, 2011. Metodologi Penelitian, USU Press, Medan.

Ghozali, Imam. 2011. Aplikasi Analisis Multivariate dengan Program IBM SPSS $19 . \quad$ Cetakan Kelima. Semarang : Penerbit Universitas Diponegoro.

Hasibuan, H. Melayu S.P. 2009.Dasar-dasar Perbankan. Cetakan Kedelapan. Jakarta : PT. Bumi Aksara.

Harahap, Sofyan Safri. 2011. Analisis Kritis atas Laporan Keuangan.Jakarta: PT. Raja Grafindo Persada

Jumingan, 2005. Analisis Laporan Keuangan. Jakarta: PT. Bumi Aksara.

Kasmir. 2008. Jakarta: Analisis Laporan Keuangan. Jakarta: PT. Raja Grafindo Persada.

Latumaerissa, (1999). Analisis Laporan Keuangan. Jakarta: Erlangga.

Mediani, Winda. 2011. Analisis Pemberian Kredit dan Risiko Kredit Pengaruhnya Terhadap Tingkat Profitabilitas PadaPT. Bank Negara Indonesia 46 (persero), Tbk Bandung. Skripsi.

Program Studi Akuntansi, Universitas Komputer Indonesia Bandung.

Mulyono, 1995. Analisis Laporan Keuangan. Jakarta: Bumi Aksara.

Sugiyarso, G. dan F. Winarni. 2005. Manajemen Keuangan Perusahaan Laporan Keuangan Pengelolaan Aktiva, Kewajiban dan Modal, Serta Pengukuran Kinerja Perusahaan, Yogyakarta : Media Pressindo.

Umar, Husein. 2003. Metode Riset Akuntansi. Cetakan Kedua Penerbit, Ghalia Indonesia, Bogor.

Paramitha, Ni Nym, Karisma Dewi dkk (2014) "variabel risiko kredit dan likuiditas terhadap profitabilitas pada perusahaan perbankan yang go public periode 2010- 2015. 